\title{
Forecasting demand for qualified labour in the South African hotel industry
}

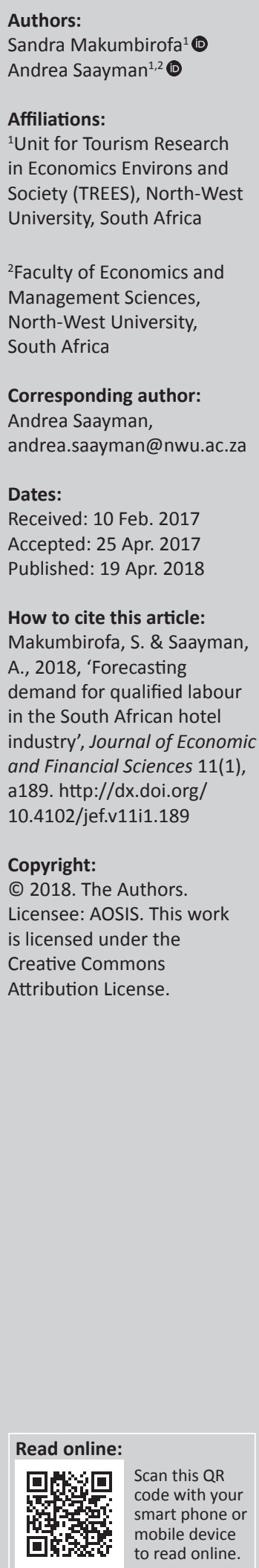

As South Africa's popularity as a tourist destination increases, the need for skilled human capital also increases. The study of skills development and human capital in all sectors of the economy has long been topical as a means to support organisational progression that can eventually lead to economic growth. Estimates suggest that tourism and hospitality employ at least $10 \%$ of the global workforce and consequently prove to be a sector that cannot be readily ignored. However, because of the complex and consumption-based nature of the tourism sector, and the general scarcity of sector-related information, data on both demand and supply of skills are few and of a qualitative rather than a quantitative nature. This research addresses this gap and aims to forecast the demand for qualified labour in the South African hotel industry. The research methodology is twofold; firstly, hotel turnover is forecasted using univariate forecasting methods and data available from Statistics South Africa; secondly, employment elasticities were determined. Linking elasticity with turnover forecasts presents an estimate of the future demand for qualified labour in the hotel industry. In addition, the typical qualifications required are based on information obtained from CATHSSETA and a survey.

\section{Introduction}

Tourism encompasses a variety of different activities that involve the interaction of people in almost all its dimensions. It is an activity that comprises a wide range of establishments, from large multinational companies to micro-enterprises, and is generally regarded as a significant source of employment in the world (UNWTO \& ILO 2014). In fact, recent estimates show that the contribution of tourism to the world economy is approximately $10 \%$ and 1 out of every 11 persons worldwide is employed in the industry (WTTC 2015a). As employment in the tourism industry varies considerably, employment contracts and working arrangements also differ, not only between types of establishments but also between regions in a country and seasons of the year. Although the industry is often criticised for its long hours and adverse working conditions, it provides a large number of people with an income and work experience, contributing to their social inclusion and personal development (UNWTO \& ILO 2014).

Given the importance of tourism as a global employer, it is interesting that employment in tourism is generally inadequately and insufficiently researched. The UNWTO and ILO (2014) state that 'the economic value of tourism in terms of employment, as source of productive labour in particular, remains inadequately measured and insufficiently studied'. They call for an improvement in the quality and comparability of tourism employment statistics in order to monitor events in the tourism labour market.

Moreover, it is recognised that sustainable tourism development that contributes to economic growth in countries can only be achieved when qualified persons are employed. Employment is therefore not only important for economic policymakers but also for competitiveness, as a destination's competitiveness depends on the quality of its human resources together with the quality of products and services. However, data on the specific educational qualifications that are demanded at different occupational levels in tourism are hard to find.

According to Saayman (2013:17), preliminary investigations have shown that poor service in the tourism industry is predominant and this can be attributed to a lack of training and inadequate supply of skilled workers, especially in developing countries such as South Africa. This, in turn, is affecting the level of service provided to tourists, and inadvertently reducing South Africa's level of competitiveness as a tourist destination. Kaplan (2004:218) found that there is a need for an integrated approach to skills development for this sector in order to realise the full benefits that 
tourism can offer an economy as a whole. Included in most of the literature on skills development in the tourism sector is the notion of inadequate skills and capacity.

The study of skills development and human capital in all sectors of the economy has long been topical as a means to support organisational progression that can eventually lead to economic growth. According to Corvers and Heijke (2004), workforce planning was initially developed during the 1960s to determine how much should be invested in education in order to supply sufficient labour to ensure sustained gross domestic product (GDP) growth. The model developed by Parnes (1962) firstly defined target growth levels of GDP, which were then used to derive labour requirements by sector and occupation group. Finally, the education required per occupation group was linked to the labour requirements and this provided the input for targeted investment in education.

This approach has not been without criticism, as it can be argued that (1) developments in the labour market are unpredictable and (2) the assumption of a one-to-one relationship between occupation and education does not take into account any substitution and adjustment processes in the case of labour market imbalances (Blaug 1967). Although the idea that workforce planning should be used to plan educational investment has now been largely abandoned, the need for well-founded labour market forecasts has remained to ensure a match between education and the labour market (Corvers \& Heijke 2004).

The current research falls into this category of labour market forecasts and aims to forecast the demand for skilled labour, and more specifically, the different levels of qualified labour that are required in the hotel industry in South Africa. Because of the complex and consumptionbased nature of the tourism sector, and the general scarcity of sector-related information, data on both demand and supply of skills are limited. This article provides a quantitative analysis of the educational qualifications that are demanded in the South African hotel industry according to the National Qualifications Framework (NQF) and the Adult Basic Education and Training (ABET). The accommodation industry was chosen because its centrality to the tourism industry is such that a substantial amount of revenue comes from accommodation compared to other tourism sectors. It is also well known to be a labour-intensive industry and therefore a key job creator in the tourism industry.

The remainder of this article is organised as follows: 'The South African scenario' section provides the necessary context of the research within the South African tourism and employment environment. The 'Factors influencing employment in the accommodation industry' section discusses the literature on factors that influence the demand and supply of labour in the accommodation industry. The 'Method and data' section involves a discussion of the data and methodology used in this study. A presentation of the results and empirical findings will follow in the 'Results' section, and the last section draws conclusions about the qualifications that are demanded in the hotel industry and recommendations based on the results.

\section{The South African scenario}

South Africa's popularity as a tourist destination has increased over the years. With just more than 700000 foreign tourists arriving in 1980, the country saw slow growth for the decade with approximately 1 million visitors to the country in 1990. After political change, tourist arrivals started to boom and 2015 saw just less than 9 million foreign tourists bracing our shores. With the increase in foreign tourism, the contribution of tourism to the South African economy also became more significant. Tourism is estimated to contribute $3 \%$ directly to the GDP, with $4.5 \%$ of all persons employed working in this industry. Through indirect linkages with other industries, the contribution to South Africa's GDP is estimated at 9.4\% (WTTC 2015b).

The inception of South Africa as a democratic nation in 1994 not only saw an increase in tourism, but also formally ended the long-run effects of biased policies and legislation that had a negative impact on the structure and efficiency of the employment sector (Rospabé 2002:185). The apartheid fabric was such that there was racial segregation in all aspects, including employment.

Employment restructuring was progressed by legislative measures in order to redress the inequalities among different racial groups and genders. The measures included the Labour Relations Act of 1995, the Employment Equity Act (EEA), the Skills Development Act of 1998 and the Promotion of Equality Act and Broad-Based Black Economic Empowerment Act (BBBEE) of 2003 (Horwitz 2013:2435).

Nevertheless, today, the country is still struggling with a high unemployment rate of $25.0 \%$, reported by SARB (2014:2). Recurring levels of unemployment in any economy give unfavourable economic and social costs. Horwitz (2013:2435) suggested that South Africa's high unemployment is mainly because of a labour market paradox of an oversupply of lowskilled labour and a shortage of appropriate skills in all sectors of the economy, including tourism. The unemployment statistics echo this, with skilled unemployment rates much lower than those of the unskilled.

The tourism industry is a labour-intensive industry and dynamic in nature such that if labour is adequately supplied, the industry can realise more economic growth. In recent years, the industry has become more competitive with unsatisfied tourists and the employees going elsewhere, as is clearly visible in the changing shares of total tourism that various countries receive. This is why it is paramount for South Africa to be equipped with workers who have the appropriate qualifications to work in the different levels of employment in the tourism industry, and produce quality service that will set it apart from other tourist destinations in the world. 


\section{Factors influencing employment in the accommodation industry}

One particular labour-intensive component of the tourism industry is the hotel and restaurant (or hospitality) industry. On a global scale, this industry is operated by highly diversified types of businesses, including large companies with more than 6000 hotels each, to small and medium-sized companies (SMEs). The large operators employ more than 150000 employees in a variety of countries but only account for $20.0 \%$ of the employment in this industry. The remaining $80.0 \%$ of people are employed in SMEs (ILO 2010).

The demand for hotels and restaurants is different to that of normal consumer goods, with consumers demanding these services mostly after normal working hours and almost around the clock. The industry is therefore characterised by irregular working hours, which include weekend and night shifts as well as increased working hours during holiday periods. The ILO (2010) confirms that this creates additional stress for workers in this industry, and especially for women who have to take care of children and household duties.

The level of demand for hotel accommodation services can be seen to change over a 24-h cycle, a weekly demand pattern (varying between a '4-day market' and a '3-day market'), a seasonal pattern (varying between off-season and on-season) and market volatility in response to external forces. Table 1 shows the typical hotel demand variability that inadvertently affects the demand for labour to work in hotels.

Throughout the day, each department and each group of employees in the department are faced with different peaks of demand for their services. The '4-day market' hotel has a high peak from Monday to Thursday nights, and suffers a drop in occupancy during the weekends (Guerrier \& Lockwood 1989:60). Consequently, the '3-day market' hotel experiences a high peak during the weekends and a low occupancy from Monday to Thursday.

Accommodation demand not only depends on weekly, monthly and yearly cycles but also on local, domestic and international factors and events that are occurring at a particular time. All these different factors affect the need for labour at different times; they also cause the demand for labour to fluctuate in response to these factors.

\begin{tabular}{ll} 
TABLE 1: Hotel demand variability. \\
\hline Time & Examples of hotel demand variability \\
\hline Daily & $\begin{array}{l}\text { Morning rush hour, guest check-out and evening check-in; peak } \\
\text { demands for restaurant services during meal time: breakfast } \\
(07: 00-10: 00), \text { lunch }(12: 00-14: 00) \text { and dinner (19:-20:00). }\end{array}$ \\
Weekly & $\begin{array}{l}\text { High occupancy during mid-week for business hotels but low in } \\
\text { weekends. More restaurant reservations at the weekend. }\end{array}$ \\
Seasonal & $\begin{array}{l}\text { Winter closure of beach resorts. High occupancy rate in ski chalets } \\
\text { during the winter. }\end{array}$ \\
Ad hoc & $\begin{array}{l}\text { Flight cancellation leading to unpredictable demand for hotel rooms } \\
\text { and meal services. 'Chance' guest bookings. }\end{array}$ \\
\hline Source: Nickson, D., 2013, Human resource management for the hospitality and tourism
\end{tabular}
Source: Nickson, D., 2013, Human resour
industries, 2nd edn., Routledge, Oxon
As the hospitality industry is reliant on relatively large numbers of workers, employers have tried to minimise their labour costs by flooding their hotels with 'marginal workers' on the basis of casual part-time workers. Such workers are reported to be women, young people, students, migrant workers and ethnic minorities, who are fitted into low-skill jobs with relatively low pay (Nickson 2013:79).

It is therefore not surprising that the supply of labour in hotels has generally come from workers who desire an income and not necessarily because they have a passion for the industry. Recent research shows that the hospitality industry is one of the least desired career choices (Coughlan, Moolman \& Haarhoff 2014:98). The reasons for this are not hard to find - the industry's characteristic low wages; casual, seasonal and temporary employment contracts; and long erratic working hours make it hard for employees to settle in the hospitality work environment. According to Horwitz (2013:2442), this lack of passion for the industry may also be resulting in incompetent delivery of service, as workers are unwilling to practise professionalism.

The labour problems in the South African hospitality industry are highlighted by CATHSSETA (2014) in their Sector Skills Plan. Of the more than 2500 hospitality enterprises inspected by the Department of Labour in 2010, 56\% were found to be in violation of labour legislation. These transgressions ranged from payment below minimum wages to over-time work without compensation and working without labour contracts.

However, this is not only a South African problem, as the industry struggles globally with the exploitation of employees by paying low wages and requiring long, irregular working hours, contributing to the deteriorating image of the industry as a long-term, stable employer. This exploitation is especially prevalent in SMEs that employ workers mainly on a casual, part-time, seasonal or temporary basis. Recent research in the Netherlands found that $70 \%$ of hospitality graduates leave the industry after 6 years (CATHSSETA 2014). According to the ILO (2010), the high turnover in the industry can be reduced through successful engagement with employees, which include training and skills development, as well as the implementation of fair labour policies.

Besides these problems, the dynamic nature of the accommodation industry, that is, high labour turnover and large numbers of seasonal and temporary positions, makes it an important employer in most economies. It is especially an attractive option for low-skilled individuals, the unemployed youth, foreigners and part-time job seekers (UNWTO \& ILO 2014).

While employment creation and facilitation of labour market participation are important in decreasing the unemployment rate, the actual allocation of vacant jobs among the unemployed is determined by the matching of job seekers and recruiting firms (Schöer, Rankin \& Roberts 2014:2). In other words, the available labour should at least have the 
minimum qualifications to work the jobs on offer. The 'Method and data' section will discuss the methodology used to forecast the qualifications demanded in hotels.

\section{Method and data}

There are four different methods for forecasting tourism labour demand and these are market signalling approach, top-down forecasting methods, time-series forecasting and the bottom-up coefficient approach. The top-down approach involves identifying the output of the industry and linking it with the labour needs in that industry and to the developments of the rest of the economy (Wong, Chan \& Chiang 2004:46). This model assumes that the realised growth in a particular industry will result in proportional growth in the demand for each occupation in that industry and is useful because it allows for long-term labour demand predictions. However, empirical evidence shows that it does not allow for changes in business environment, job turnover and occupational mobility.

The labour market signalling methods are based on 'market signals' such as changes in relative wages, employment rates by skills and training, among other things. These signals are then used to identify job opportunities as well as skills gaps so as to emphasise the benefits of investing in specific skills (Wong et al. 2004:49), and these models are used when data are insufficient to build a time-series model. This article used a time-series forecasting method together with the bottomup approach, which are subsequently reviewed.

\section{Time-series methods}

Box, Jenkins and Reinsel (2008:1) describe a time series as a series of observations that are taken successively over time. This is achieved by substituting the structural limits essential for decreasing the sampling error and improving forecasts, with limits that are determined by the data. These methods are either univariate (a single variable is forecasted based on its past observations) or multivariate (a forecast of several variables).

Time-series methods are advantageous for short-run forecasts because they require relatively less time and energy than causal methods in the short run (Chu 1998:598). However, they do not explore the reasons that cause a change in labour requirements and structures.

The simplest of all the time-series methods of forecasting are the naïve methods, which provide a benchmark for comparison of all other methods of forecasting. These assume that the past will repeat itself and any trends, seasonality or cycles are either reflected in the previous period's demand or do not exist. For the seasonal naïve method, Athanasopoulos et al. (2011:828) record that all forecasts for seasonal data are equal to the most recent observations of the corresponding season. Therefore, the equation becomes:

$$
\hat{y}_{(t+h \mid t)}=y_{t}+h-k m \ldots \ldots, k=\lceil(h-1) / m\rceil+1,
$$

where $\hat{y}_{(t+h \mid t)}$ denotes the $h$-step ahead forecast based on all of the data up to time $t, y_{t}$ is the last observed value and $m$ is the seasonal period.

The second most popular time-series method used in the literature is the ARIMA model. An ARIMA time-series model consists of three broad components, a non-seasonal autoregressive (AR) component, the integrated (I) component as well as a non-seasonal moving average (MA) component. As ARIMA models comprise different variations, they are regarded as a family of models courtesy of Box and Jenkins (1976), who developed a strategy that guides the researchers in selecting the appropriate model out of a varied family of models. The ARIMA technique includes three stages, namely (1) identification, (2) estimation and (3) diagnostic checking to ensure model consistency.

For seasonal time series, such as monthly and quarterly time series, the ARIMA was expanded to include seasonal components. The seasonal ARIMA model with seasonal difference $(D)$ is composed of both seasonal and non-seasonal parts, namely, the seasonal part, which has its own AR and MA parameters of orders $(P)$ and $(Q)$, and the non-seasonal part with $\mathrm{AR}$ and MA components of orders $p$ and $q$ (Kulendran \& Wong 2005:163). In this model, the capitalised letters correspond to the seasonal components of the model.

According to Goh and Law (2002:502), the seasonal ARIMA model can be represented by ARIMA $(p, d, q)(P, D, Q)_{\mathrm{s}}$ :

$\phi_{p}(\mathrm{~B}) \varphi_{p}\left(\mathrm{~B}^{s}\right) \nabla^{\mathrm{d}} \nabla_{\mathrm{s}}^{\mathbf{D}} \mathbf{y}_{\mathrm{t}}=\theta_{\mathbf{q}}(\mathrm{B}) \Theta_{\mathrm{Q}}\left(\mathrm{B}^{\mathrm{s}}\right) \varepsilon_{\mathrm{t}}$

where $\mathrm{B}$ is the backward shift operator, $\phi_{p}(\mathrm{~B}), \theta_{q}(\mathrm{~B}), \varphi_{p}\left(\mathrm{~B}^{\mathrm{s}}\right)$ and $\Theta_{\mathrm{Q}}\left(\mathrm{B}^{\mathrm{s}}\right)$ are polynomials in $\mathrm{B}$ and $\mathrm{B}^{\mathrm{s}}$ of non-seasonal and seasonal orders of $p, q, P$ and $Q$, respectively, and $\varepsilon_{\mathrm{t}}$ is the white noise term (Kulendran \& Wong 2005:164). The ' $s$ ' indicates the order of periodicity or seasonality, $\nabla^{\mathrm{d}}$ is the nonseasonal differencing operator and $\nabla_{s}^{D}$ is the seasonal differencing operator (Shen, Li \& Song 2009:695).

A third time-series method that has proven to be an effective model is exponential smoothing. It involves forecasting from a rapidly increasing weighted average of previous observations and it seeks to isolate trends or seasonality from irregular variation (Cho 2003:324). This is performed by way of giving the latest observations more weight than the earlier observations. The forecast is derived as a weighted average of previous observations, with the weights declining geometrically as follows (Carnot, Koen \& Tissot 2005:86):

$P\left(X_{T+1}\right)=\alpha\left(X_{T}+\beta X_{T-1}+\beta^{2} X_{T-2}+\ldots+\beta^{j} X_{T-j}\right), \quad$ [Eqn 3]

where $0<\beta<1$.

In other words, the weighting is exponentially decaying with the most recent data getting the most weight and those further back receiving progressively less weight (Goh \& Law 2002:502). According to Billah et al. (2006:239), these models 
have three simple variations that are commonly used: simple exponential smoothing, trend-corrected exponential smoothing and Holt-Winters' method.

The above methods all assume linearity in the time series. To control for possible non-linearities, this research also employs the basic structural model (BSM), which is based on the assumption that a time-series model is composed of a structure that is the summation of a stochastic trend; seasonal, irregular components; and an error term (Zhou-Grundy \& Turner 2014:2). As the BSM models the trend, seasonal and an irregular component, it has the advantage of allowing an instantaneous interpretation and therefore works as a natural vehicle for making forecasts (Harvey \& Peters 1990:89).

Assuming $y_{t}$ is the observed variable, the BSM has the form:

$y_{t}=\mu_{t}+\gamma_{t}+\varepsilon_{t}, t=1$

where $\mu_{t}$ is the trend, $\gamma_{t}$ is the seasonal component and $\varepsilon_{t}$ is the irregular component.

The process generating the trend is a local approximation to a linear trend. The level and slope both change slowly over time according to a random-walk mechanism. The seasonal pattern changes slowly through a mechanism that makes sure that the total of the seasonal components over any $s$ consecutive time periods has an anticipated value of zero and a variance that remains constant over time (Harvey \& Todd 1983:300).

\section{Bottom-up approach}

The bottom-up approach is one of the methods that the literature identifies for workforce planning. This method employs a labour multiplier approach by assuming that each job assignment will demand a constant level of labour requirement per unit of assignment expenditure and will follow a standard demand pattern (Wong et al. 2004:45). The data collected from each assignment are used to link the supply of labour for an assignment and number of days worked with past expenditure. This ratio is then used to predict the estimated labour demand by occupation as shown in equations 5 and 6 .

$L_{s x}^{J}=\frac{D_{s x}^{J}}{E_{x}^{J}}$

$$
L_{S}^{D}=\sum_{x} E_{x(e s t)}
$$

Where:

$L_{s x}^{J}$ is the labour multiplier of trade $s$ at stage $x$ of the assignment type $j$

\footnotetext{
$L_{S}^{D}$ is the total labour demand of trade $s$ for a particular hotel assignment
}

$D_{s x}^{J}$ is the number of days worked of trade $s$ at stage $x$ of the assignment type $j$

$E_{x}^{J}$ is the assignment expenditure at stage $x$ of the project type $j$

$E_{x(e s t)}$ is the estimated project expenditure at stage $x$.

While this method is mainly used for project-based forecasting, it is similar to the approach applied by the Human Science Research Council (HSRC) in determining labour demand for South Africa (see Whiteford et al. 1999).

\section{Qualification assessments}

The forecasts obtained from using the above methods must be linked to the appropriate qualifications. The qualifications in the hotel industry were assessed according to level of skills, qualifications and corresponding Organising Framework for Occupations (OFO) codes. According to the South African Department of Higher Education and Training (2013:1), OFO is a coded occupational classification system used by the Department of Higher Education and Training as a key tool for identifying, reporting and monitoring skills demand and supply in the South African labour market (South Africa Department of Higher Education and Training 2013:1).

For the purposes of uniformity, this research assumes the following classification according to the Quantec and StatsSA classification of skills:

- Skilled: includes professional, semi-professional and technical occupations; and managerial, executive and administrative occupations.

- Semi-skilled: includes clerical occupations; sales occupations; transport, skilled agriculture, craft and related trade occupations; plant and machine operator occupations; delivery and communications occupations; service occupations; farmer, farm manager; artisan, apprentice and related occupations; production foreman and production supervisor.

- Unskilled: includes elementary and domestic worker occupations; and all that are neither skilled nor semiskilled.

According to the South African Qualifications Authority (SAQA 2015), the NQF consists of 10 qualification levels, as shown in Table 2.

In the categorisation, according to Kraak (2005:69), skilled labour has acquired a higher education degree or postgraduate courses (NQF levels 6-10); semi-skilled labour has acquired a matric certification or diploma (NQF levels 4-5); and unskilled labour has acquired pre-matric qualification (NQF levels 1-3). This study uses this classification to categorise the level of skill that employees have. 
TABLE 2: National Qualifications Framework levels.

\begin{tabular}{lcl}
\hline $\begin{array}{l}\text { Educational qualification (Higher } \\
\text { education qualifications framework; } \\
\text { General and further education and } \\
\text { training qualification sub-framework) }\end{array}$ & Levels & $\begin{array}{l}\text { Occupational qualification } \\
\text { (Occupational qualifications } \\
\text { sub-framework) }\end{array}$ \\
\hline $\begin{array}{l}\text { Doctoral degree } \\
\text { Doctoral degree (professional) }\end{array}$ & 10 & \\
$\begin{array}{l}\text { Master's degree } \\
\text { Master's degree (professional) }\end{array}$ & 8 & Occupational certificate \\
$\begin{array}{l}\text { Bachelor honours degree } \\
\text { Postgraduate diploma }\end{array}$ & & \\
$\begin{array}{l}\text { Bachelor's degree } \\
\text { Bachelor's degree }\end{array}$ & 7 & Occupational certificate \\
$\begin{array}{l}\text { Advanced diploma } \\
\text { Diploma }\end{array}$ & 6 & Occupational certificate \\
Advanced certificate & & Occupational certificate \\
Higher certificate & 5 & Occupational certificate \\
\hline National certificate & 4 & Occupational certificate \\
Intermediate certificate & 3 & Occupational certificate \\
\hline Elementary certificate & 2 & Occupational certificate \\
\hline General certificate & 1 &
\end{tabular}

Source: South African Qualifications Authority (SAQA), 2015, National qualifications framework: Sub-frameworks and qualification type, viewed 13 November 2015, from http:// www.saqa.org.za/docs/brochures/2015/updated $\% 20$ nqf $\% 20$ levevl $\% 20$ descriptors.pdf

\section{Data sources and variables used}

The research consists of three phases of analysis: firstly, the output elasticity of demand for various qualifications in the hospitality industry is determined; secondly, output in the hotel accommodation sector is forecasted and the elasticities found in the first analysis applied to the forecasts to obtain labour demand forecasts; and thirdly, the labour forecasts are linked to qualifications typically found in the hotel industry.

For the first part of the analysis, employment data from 1970 to 2014, including statistics on the skilled, semi-skilled and unskilled labour in the hospitality industry (catering and accommodation), were extracted from the Quantec database. A visual plot of the changing demand for different skills in this industry is shown in Figure 1.

It is evident that the demand for skilled labour is showing an increasing trend, while the demand for highly skilled labour remains relatively flat. The demand for semi-skilled and unskilled labour also shows some stagnation. For the purposes of analysis in this article, the data of skilled and highly skilled labour are aggregated and the analyses are compiled using two series, namely, skilled labour (consisting of highly skilled and skilled labour) and unskilled labour (consisting of semi-skilled and unskilled labour). The employment data, together with real output and labour productivity, are subsequently used to determine the labour elasticities in this sector.

The variable used in the second part of the analysis, timeseries forecasts (discussed above), was income from hotel accommodation in South Africa. The data were extracted from the Statistics South Africa (StatsSA) database as monthly income from hotel accommodation, deflated using the Consumer Price Index (CPI) for restaurants and hotels, and converted into logarithms over the period September 2004 to January 2015.
While the analysis is mainly based on the data obtained from StatsSA and the Quantec database, the relevant occupations and resulting qualifications are assessed using information obtained from both primary sources as well as CATHSSETA. The CATHSSETA data gave information on 236 hospitality establishments under Standard Industrial Classification (SIC) codes 64101 and 64104. According to the South African Department of Higher Education and Training (2013:19), the SIC code 64101 includes hotels, motels, boatels and inns that are registered with the South African Tourism Board, and the SIC code 64104 includes hotels, motels, boatels and inns that are not registered with the South African Tourism Board. To enhance and confirm the information obtained from CATHSSETA, data were also collected through a web-based survey, where a questionnaire was administered to a stratified sample of star-graded hotels in South Africa. The data gathered from the questionnaires provided information about current and expected minimum education requirements according to occupation as well as the lack of qualified labour.

\section{Results}

The results are discussed in the three stages of analyses described above.

\section{The labour elasticities}

The data obtained from Quantec were used in determining the labour elasticities, based on a typical labour demand function. The data were scrutinised for stationarity using the augmented Dickey-Fuller test and as the data were found to be non-stationary, all variables were first differenced. The Johansen test did not show any significant co-integrating relationships and therefore the regression models were estimated using the first difference specification as in equation 7:

$$
\begin{aligned}
\Delta \ln L_{t}^{i}= & \beta_{0}+\beta_{1} \Delta \ln \left(\frac{1}{A_{t}}\right)+\beta_{2} \Delta \ln Y_{t}+\beta_{3} \Delta \ln W_{t}+\varepsilon_{t}, \\
& \text { with } i=s, u .
\end{aligned}
$$

The $s, u$ represents skilled and unskilled labour, respectively, $A_{t}$ indicates labour productivity, $Y_{t}$ the output in the hospitality industry and $W_{t}$ the average wage rate. In each equation, three dummy variables were added to control for structural breaks in the data (see Figure 1); these were for 2010 (both models), 2005 (both models) and 2008 (unskilled labour) and 2001 (skilled labour). In order to obtain wellbehaved error terms, AR terms had to be included to control for autocorrelation. Given this, the errors of both the models for skilled and unskilled labour have normally distributed error terms, with no serial correlation. In none of the equations was the wage rate significant, and this is ascribed to the aggregation of data (i.e. the wage rate is only available as an aggregate, not for skilled and unskilled labour, respectively).

The final models therefore exclude the wage rate, as an exclusion of the variable led to improved information criteria 


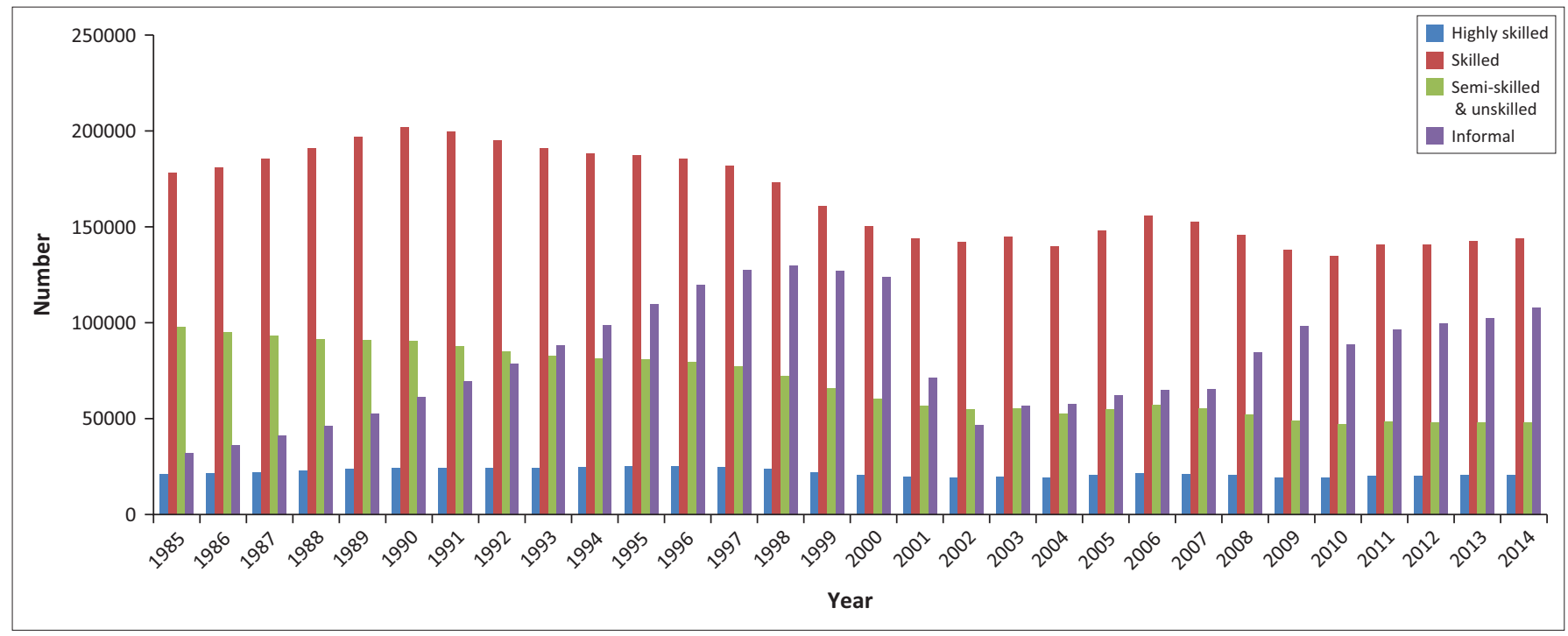

Source: Quantec, n.d., Easydata, viewed n.d., from https://www.quantec.co.za/easydata/

FIGURE 1: Employment according to skill level in the hospitality industry of South Africa.

TABLE 3: Regression results: Labour coefficients.

\begin{tabular}{lcc}
\hline Variable/statistic & Skilled labour $\left(\Delta \ln L^{s}\right)$ & Unskilled labour $\left(\Delta \ln L^{\varphi}\right)$ \\
\hline Constant & -0.055 & $-0.014^{* *}$ \\
& $(0.082)$ & $(0.006)$ \\
$\Delta \ln (1 /$ At) & $0.339 * * *$ & $0.233^{* * *}$ \\
& $(0.054)$ & $(0.077)$ \\
$\Delta \ln Y$ & $0.166^{* * *}$ & $0.136^{*}$ \\
& $(0.055)$ & $(0.076)$ \\
DUM2010 & $0.034^{* *}$ & $0.055^{* *}$ \\
& $(0.015)$ & $(0.023)$ \\
DUM2005 & $0.047^{* * *}$ & $0.039 * *$ \\
& $(0.010)$ & $0.015)$ \\
DUM2001 or DUM2008 & $0.059 * * *$ & -0.022 \\
& $(0.020)$ & $(0.018)$ \\
Adj $R$-squared & 0.718 & 0.653 \\
AIC & -4.796 & -4.688 \\
SIC & -4.420 & -4.358 \\
Jarque-Bera & 0.467756 & 1.230033 \\
Breusch-Pagan-Godfrey & 0.67796 & 1.901509 \\
\hline
\end{tabular}

AIC, Akaike Information Criterion; SIC, Standard Industrial Classification. ${ }^{*} \alpha=10 \% ;{ }^{* *} \alpha=5 \% ;{ }^{* * *} \alpha=1 \%$; probabilities in parenthesis.

and a higher adjusted $R$-squared. The results of the estimations are shown in Table 3, and it is evident that the labour elasticity for skilled labour is 0.166 and is significant. However, the labour elasticity for unskilled labour is only 0.136 and it is only significantly at a $10 \%$ level. The Akaike Information Criterion (AIC) and SIC are low - the normality test shows that the error term is normally distributed, while the Breusch-Pagan-Godfrey test shows that the data do not suffer from heteroscedasticity.

The labour elasticity was then applied to forecasted values of real hotel income, obtained from StatsSA as a monthly series (starting September 2004 until December 2014), in order to derive forecasts for skilled and unskilled labour demand. These forecasts were obtained using the following time-series methods (described above):

- naïve forecast (as baseline)

- SARIMA

- Holt-Winters

- unobserved components model (or BSM).
TABLE 4: Comparison of the accuracy of the forecasting models using mean average percentage error.

\begin{tabular}{lcccc}
\hline Forecasting model & \multicolumn{4}{c}{ Average MAPE } \\
\cline { 2 - 5 } & $\mathbf{1}$ month & $\mathbf{6}$ month & $\mathbf{1 2}$ months & $\mathbf{2 4}$ months \\
\hline Naïve & 2.736 & 5.535 & 5.047 & 4.751 \\
SARIMA $(0,1,1)(0,1,1)$ & 1.372 & 3.869 & 4.492 & 3.335 \\
Holt-Winters (additive) & 1.591 & 1.954 & 2.955 & 3.581 \\
Holt-Winters (multiplicative) & 1.644 & 1.969 & 2.963 & 3.609 \\
BSM & 1.746 & 2.469 & 3.671 & 4.524
\end{tabular}

BSM, basic structural model; MAPE, mean average percentage error.

TABLE 5: Comparison of the accuracy of the forecasting models using root mean squared percentage error.

\begin{tabular}{lcccc}
\hline Forecasting model & \multicolumn{4}{c}{ Average RMSPE } \\
\cline { 2 - 5 } & $\mathbf{1}$ month & $\mathbf{6}$ months & $\mathbf{1 2}$ months & $\mathbf{2 4}$ months \\
\hline Naïve & 1.807 & 2.552 & 2.500 & 2.379 \\
SARIMA $(0,1,1)(0,1,1)$ & 1.280 & 5.226 & 2.266 & 2.004 \\
Holt-Winters (additive) & 1.378 & 1.503 & 1.860 & 2.065 \\
Holt-Winters (multiplicative) & 1.401 & 1.509 & 1.867 & 2.073 \\
BSM & 1.746 & 2.960 & 5.213 & 6.368 \\
\hline
\end{tabular}

BSM, basic structural model; RMSPE, root mean squared percentage error

To determine which forecasts were the most efficient, the data set was divided into a development sample (ranging from 2004M09 to 2012M12) and a subsequent forecast sample (ranging from 2013M01 to 2014M12). The models were developed using the development sample data and forecasts were obtained for the following 24 months. To measure the accuracy of the forecasts, the forecasted values were compared to the actual values, using the mean average percentage error (MAPE). The model with the lowest MAPE over the 24 months is then used to forecast real income up to 2019.

The forecasting results of all the five models are compared in Tables 4 and 5 using the MAPE and the root mean squared percentage error (RMSPE), respectively (full results are available from the authors on request, as only the forecasting accuracy results are shown because of length limitations). 
TABLE 6: Forecasted changes in hotel income, skilled and unskilled labour.

\begin{tabular}{lcccccc}
\hline Year & $Y^{f}(\mathbf{R m})$ & $\begin{array}{c}\text { Cumulative } \% \\
\text { change in } Y\end{array}$ & Ls $^{f}$ & $\begin{array}{c}\text { Cumulative \% } \\
\text { change in } \mathrm{L}^{s}\end{array}$ & Luf $^{f}$ & $\begin{array}{c}\% \text { change } \\
\text { in } \mathrm{L}^{u}\end{array}$ \\
\hline 2014 & 23592 & - & 164683 & - & 47804 & - \\
2015 & 24787 & 5.064 & 166069 & 0.842 & 48135 & 0.692 \\
2016 & 25347 & 7.440 & 166720 & 1.237 & 48290 & 1.017 \\
2017 & 25921 & 9.870 & 167386 & 1.641 & 48449 & 1.350 \\
2018 & 26507 & 12.355 & 168066 & 2.054 & 48612 & 1.690 \\
2019 & 27106 & 14.897 & 168762 & 2.477 & 48778 & 2.037 \\
\hline
\end{tabular}

It is evident that all the fitted models are better than the baseline naïve model. Over a 1-month period, the seasonal ARIMA model outperforms the Holt-Winters models, and this is also true for the 24 months. The Holt-Winters (additive) model is superior over the 6- and 12-month periods. There is, however, little difference between the various models, but as the seasonal ARIMA almost reaches $5.0 \%$ error and the Holt-winters method never exceeds a $4.0 \%$ error, the forecasts were performed using the HoltWinters additive method instead.

The labour elasticities (Table 3) of the hospitality sector as a whole were applied to the real hotel forecasts in order to derive the demand for labour that arises from an increase in income from hotels. Applying the Holt-Winters method to the real income of hotel data and forecasting until 2019, the forecasts obtained are shown in Table 6. Based on the labour elasticities shown in Table 3 ( 0.166 for skilled labour and 0.136 for unskilled labour), a $10.0 \%$ increase in hotel income will result in a $1.66 \%$ increase in demand for skilled labour and a 1.36\% increase in demand for unskilled labour.

In order to further the analyses, the percentage changes in skilled and unskilled labour demands were determined as indicated in Table 6. The second column shows the forecasted (cumulative) changes in income from hotels in rand millions, $Y f(R m)$, and the third column shows the percentage change in hotel income. The Lsf and Luf represent the cumulative change in skilled labour and unskilled labour, respectively. Consequently, the forecasted changes are cumulative changes from the base year 2014 . Based on historical data, real income of hotels is expected to increase by $5.1 \%$ in 2015 cumulatively compared to 2014 , while the income is expected to be almost $15.0 \%$ (i.e. 14 897) higher in 2019 than in 2014. This shows a steady increase in real income over the next 4 years leading to 2019 .

Based on the elasticities found in Table 3, Table 6 shows that the demand for skilled labour is expected to have a cumulative increase by approximately $1.0 \%$ in 2015 compared to 2014 , and $2.5 \%$ more skilled labourers will be demanded by 2019 compared to 2014. The increase in demand for unskilled labour is slightly less, with only a $0.7 \%$ increase in 2015 and a $2.0 \%$ increase between 2014 and 2019. This further emphasises that more and more skilled employees will be demanded in the future than unskilled employees.

An increase in demand of 1386 skilled workers (166 069 $164683)$ and 331 unskilled workers (48 135 - 47 804) in 2015 alone is predicted, and a cumulative demand of 4079 skilled workers and 974 unskilled workers by 2019. This increase in demand for more workers in the next 5 years is encouraging as it suggests that the South African economy may well be working towards a decrease in unemployment, if job seekers are adequately skilled to be hired. Bearing in mind that although hotels are showing an increasing demand for skilled than unskilled labour, the semi-skilled and unskilled job seekers can still find job vacancies for which they are eligible.

It is important to note that this increase in labour demand is only because of an increase in sales, it does not take into account replacement demand because of retirement or job rotation, or current vacancies that exist. Considering that most employees leave their jobs for different reasons, for instance, long illness, injury, voluntary quits and in most cases involuntary firing, a more all-inclusive approach to account for replacement demand would be to include all these other reasons for leaving a job. Thomas (2015:70) supports this idea by emphasising that the inclusion of additional channels of departure from the workplace would definitely be best practice in labour market forecasting.

In fact, current vacancies in these occupations are 3.0\% for chefs and $2.1 \%$ for managers in terms of demand for labour because of an increase in sales. With regard to replacement demand, the data showed that $2.8 \%$ and $2.4 \%$ of chefs and managers, respectively, retire within 5 years. With this short span of a hotel working life, it is important that more and more job seekers equip themselves with the right educational qualifications to fill these positions. If the older managers and chefs are retiring within the next 5 years, then the new recruits need to be available now, in order to benefit from onthe-job training from the experienced employees. With this in mind, efforts to retain the critically scarce occupations should be made by hotel owners through performance appraisals and opportunities for career growth within their hotels.

The data also showed that an approximately $2.8 \%$ staff turnover is expected per year because of migration (migration within South African hotels and outside South Africa) and approximately $0.6 \%$ because of death. These figures show that replacement demand plays a vital role in the overall demand for labour in hotels in order to fully capture the causes for an increase in demand for future labour.

\section{Qualification and job forecasts}

The results above show a clear increase in demand for skilled labour, but exactly what types of qualifications are demanded by hotels? To shed light on this question, results from the questionnaire were used and enhanced by information obtained from CATHSSETA.

Based on the distributed questionnaire, the minimum qualifications required for different occupations in a hotel are shown in Figure 2. It is evident that all manager occupations require at least a senior certificate, and more often require at 


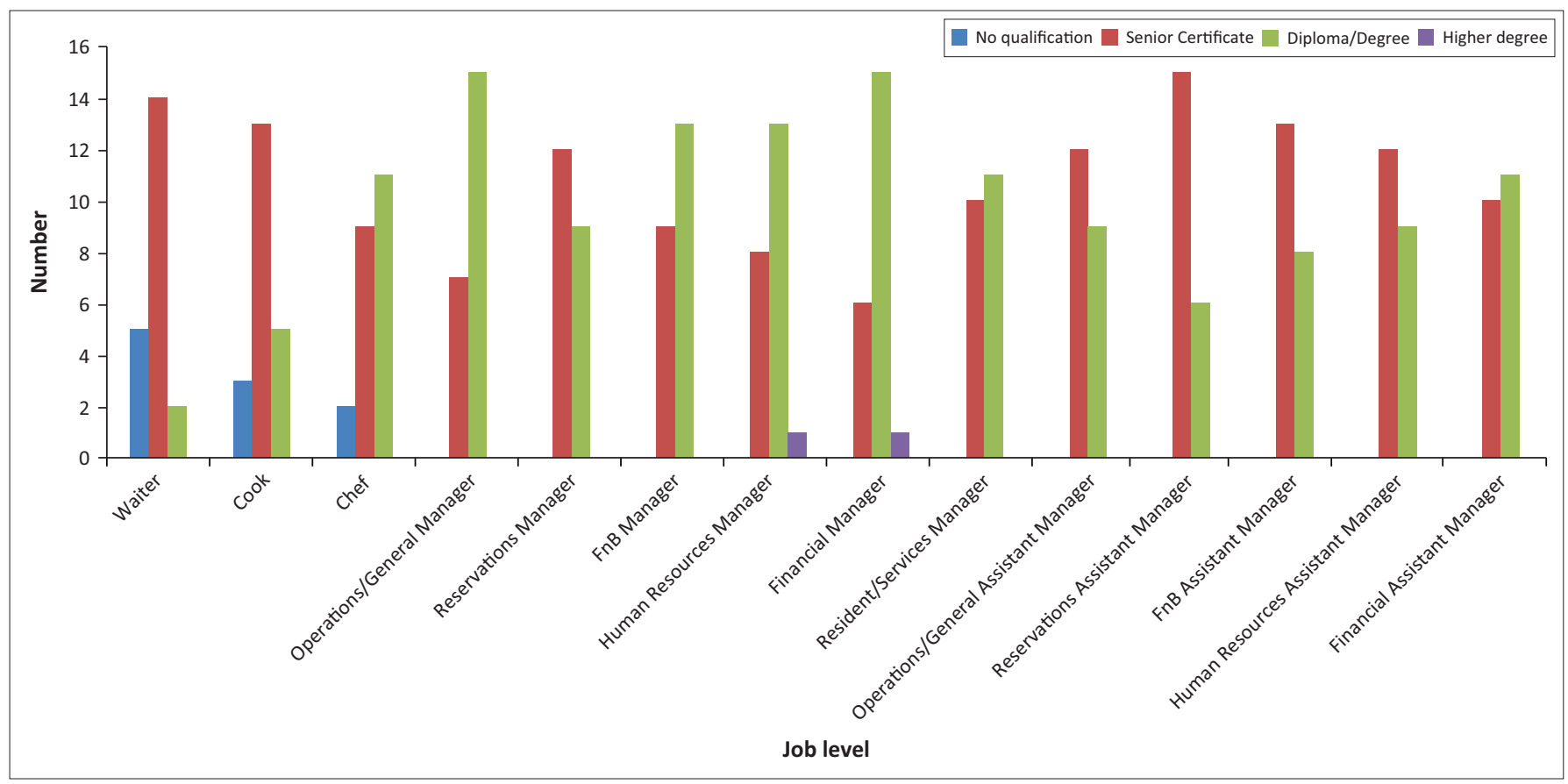

FIGURE 2: Qualification requirements according to job level.

least a diploma or degree. The qualification requirements for the chef occupation are also generally higher. Assistant managers, cooks and waiters are the only occupations where the qualification requirements are less, that is, they are biased towards semi-skilled and unskilled labour.

It is also noteworthy that higher degrees are only required for financial and human resource managers. A possible explanation of this could be the fact that the level of skill that financial and human resources managers should possess is specialised from a hotel perspective. Therefore, employees wishing to be employed under these roles should possess a higher degree in order to be suitably qualified.

This is largely echoed by the CATHSSETA (2014) data. All management occupations in the hospitality sector require qualifications of NQF level 6, with the chef occupation requiring NQF level 4 qualifications.

These results qualify the industry's characteristic demand for low-skilled to semi-skilled workers for its positions. Most workers should at least have a senior certificate to qualify to work in hotels at all levels of occupations in a hotel. The critically scarce occupations, according to CATHSSETA (2014), include chefs, hotel managers, restaurant managers, general managers and operations managers. It is important to note that these occupations require a relatively higher level of qualification in order to be suitably qualified for the job.

\section{Conclusion}

The aim of this article was to analyse the demand for skilled labour, and more specifically the different levels of qualified labour that are required in the tourism accommodation industry in South Africa, and provides a forecast of future output and employment requirements in this industry. The increase in the importance of tourism and the relative labour intensity of accommodation as a key part of the tourism offering in a country are the reasons why this is an important question to investigate. Coupled with the fact that while unskilled unemployment in South Africa hovers above $40.0 \%$, skilled unemployment is less than $6 \%$, the focus on the demand for skilled labour remains paramount within the South African context.

The main challenge faced in this research is the fact that data are not readily available, leaving one with the task to sensibly combine different data sources. The approach to forecast labour demand followed in this research was that of a bottom-up coefficients approach combined with timeseries forecasts. The coefficients were based on data from Quantec for the hospitality industry and both skilled and unskilled labour demand equations were estimated in order to derive labour elasticities. The bottom-up coefficient approach is normally followed in determining the workforce demand for a project, where the projected cost of the project is multiplied with the labour coefficients to derive the workforce needs for the project. However, this article shows that when combining time-series forecasts with the bottom-up coefficient approach, it can also be used to determine industry workforce demand. Therefore, the combination of the two approaches in forecasting industry workforce demand is an important methodological and theoretical contribution of this article.

In conclusion, the demand for skilled labour is predicted to grow by approximately $1.0 \%$ in 2015 compared to 2014 , and $2.5 \%$ more skilled labourers will be demanded by 2019 . This translates to an increase in demand of 1386 skilled workers 
and 331 unskilled workers in 2015 alone, and a cumulative demand of 4079 skilled workers and 974 unskilled workers by 2019. The increase in demand for unskilled labour is therefore slightly less, with only a $0.7 \%$ increase in 2015 and a 2.0\% increase between 2014 and 2019. This has important practical implications for unskilled labour, as the accommodation industry has traditionally been viewed as a significant employer of unskilled labour. Recent trends in the data as well as the results of this research show that this is changing, and demand in this industry is shifting towards more skilled labour. The industry survey confirmed this trend, with almost all occupations, except waiters and cooks, requiring at least a senior certificate.

The critically scarce occupations, according to CATHSSETA, include chefs, hotel managers, restaurant managers, general managers and operations managers. In terms of replacement demand, $2.8 \%$ of hotel staff turnover is expected per year because of migration and a further $0.6 \%$ is expected per year because of retirement. Therefore, replacement demand constitutes a significant part of overall demand for labour in hotels. This is not surprising, given the fact that labour turnover in the hospitality industry is high throughout the world, which necessitates the improvement of work conditions for labourers in this industry. The results from this research confirm that, in South Africa, more should be accomplished to ensure better working and contract conditions for labourers in the South African accommodation industry if labour turnover is to be reduced.

According to the data from the questionnaire, the conclusions are that manager occupations require at least a senior certificate, and more often require at least a diploma or degree. The qualification requirements for the chef occupations are also generally higher. Assistant managers, cooks and waiters are the only occupations where the qualification requirements are less, that is, they are biased towards semi-skilled and unskilled labour. Higher degrees are only required for financial and human resource managers. The CATHSSETA confirms the same trend with management occupations in the hospitality sector requiring qualifications of NQF level 6, with the chef occupation requiring NQF level 4 qualifications.

In terms of future research recommendations, it might be more useful to forecast future labour supply concurrently with labour demand. This would work to give information on the imbalance in the labour market, and policy recommendations can be made to minimise this imbalance, reduce unemployment and ensure that employers have adequately qualified and skilled labour. Estimations of future demand according to seasons or periods of high and low demand would also be beneficial in giving information for part-time workers.

\section{Acknowledgements}

The authors would like to thank Duduzile Gama and Shivanthini Nagalingam from CATHSSETA who supplied data used in this research and the anonymous referees for their comments.

\section{Competing interests}

The authors declare that they have no financial or personal relationships which may have inappropriately influenced them in writing this article.

\section{Authors' contributions}

This research formed part of S.M.'s Masters dissertation, under the supervision of A.S.

\section{References}

Athanasopoulos, G., Hyndman, R.J., Song, H. \& Wu, D.C., 2011, 'The tourism forecasting competition', International Journal of Forecasting 27, 822-844. https://doi.org/10.1016/j.ijforecast.2010.04.009

Billah, B., King, M.L., Snyder, R.D. \& Koehler, A.B., 2006, 'Exponential smoothing mode selection for forecasting', International Journal of Forecasting 22, 239-247. https://doi.org/10.1016/j.ijforecast.2005.08.002

Blaug, M., 1967, 'Approaches to educational planning', The Economic Journal 77(306), 262-287. https://doi.org/10.2307/2229304

Box, G.E.P. \& Jenkins, G.M., 1976, Time series analysis, forecasting and control, rev. edn., Holden-Day, San Francisco, CA.

Box, G.E.P., Jenkins, G.M. \& Reinsel, G.C., 2008, Time series analysis: Forecasting and control, 4th edn., Wiley, Hoboken, NJ.

Carnot, N., Koen, V. \& Tissot, B., 2005, Economic forecasting, 1st edn., Palgrave Macmillan, New York.

Cho, V., 2003, 'A comparison of three different approaches to tourist arrival forecasting', Tourism Management 24, 323-330. https://doi.org/10.1016/S02615177(02)00068-7

Chu, F., 1998, 'Forecasting tourism demand in Asian-Pacific countries', Journal of Tourism Research 24(3), 597-615. https://doi.org/10.1016/S0160-7383(98)00012-7

Corvers, F. \& Heijke, H., 2004, Forecasting the labour market by occupation and education: Some key issues, Research centrum voor Onderwijs en Arbeidsmarkt (ROA-W-2004/4), Universiteit Maastricht, Maastricht.

Coughlan, L., Moolman, H. \& Haarhoff, R., 2014, 'External job satisfaction factors improving the overall job satisfaction of selected five-star hotel employees', South African Journal of Business Management 45(2), 97-107.

Culture, Arts, Tourism, Hospitality and Sport Sector Education and Training Authority (CATHSSETA), 2014, Sector skills plan 2014/15-2016/17, CATHSSETA Johannesburg.

Goh, C. \& Law, R., 2002, 'Modeling and forecasting tourism demand for arrivals with stochastic nonstationarity seasonality and intervention', Tourism Management 23, 499-510. https://doi.org/10.1016/S0261-5177(02)00009-2

Guerrier, Y. \& Lockwood, A.J., 1989, 'Managing flexible working in hotels', in T. Baum (ed.), Hospitality management, vol. 3, pp. 59-72, Sage, London.

Harvey, A.C. \& Peters, S., 1990, 'Estimation procedures for structural time series models', Journal of Forecasting 9, 89-108. https://doi.org/10.1002/for.3980090203

Harvey, A.C. \& Todd, P.H.J., 1983, 'Forecasting economic time series with structural and Box-Jenkins models: A case study', Journal of Business \& Economic Statistics 1(4), 299-307.

Horwitz, F.M., 2013, 'An analysis of skills development in a transitional economy: The case of the South African labour market', International Journal of Human Resource Management 24(12), 2435-2451. https://doi.org/10.1080/09585192.2 013.781438

International Labour Organization (ILO) 2010 , Developments and challenges in the hospitality and tourism sector, Issues paper for discussion at the Global Dialogue Forum for the Hotels, Catering, Tourism Sector, International Labour Organization, Forum for theva.

Kaplan, L., 2004, 'Skills development in tourism: South Africa's tourism led development strategy', GeoJournal 60, 217-227. https://doi.org/10.1023/B:GEJO. 0000034729.04687.a2

Kraak, A., 2005, 'Human resources development and the skills crisis in South Africa: The need for a multi-pronged strategy', Journal of Education and Work 18(1) 57-83. https://doi.org/10.1080/1363908052000332311

Kulendran, N. \& Wong, K.K.F., 2005, 'Modelling seasonality in tourism forecasting', JournalofTravelResearch44,163-170.https://doi.org/10.1177/0047287505276605

Nickson, D., 2013, Human resource management for the hospitality and tourism industries, 2nd edn., Routledge, Oxon.

Parnes, H.S., 1962, Forecasting educational needs for economic and socia development, OECD, Paris.

Quantec, n.d., Easydata, viewed n.d., from https://www.quantec.co.za/easydata/

Rospabé, S., 2002, 'How did labour market racial discrimination evolve after the end of apartheid? An analysis of the evolution of employment, occupational and wage discrimination in South Africa between 1993 and 1999', The South African Journal of Economics 70(1), 185-217. https://doi.org/10.1111/j.1813-6982.2002. tb00043.x 
Saayman, M., 2013, En route with tourism: An introductory text, 4th edn., Juta, Cape Town.

Schöer, V., Rankin, N. \& Roberts, G., 2014, 'Accessing the first job in a slack labour market: Job matching in South Africa', Journal of International Development 26(1) 1-22. https://doi.org/10.1002/jid.2838

Shen, S., Li, G. \& Song, H., 2009, 'Effect of seasonality treatment on the forecasting performance of tourism demand levels', Tourism Economics 15(9), 693-708. https://doi.org/10.5367/000000009789955116

South Africa Department of Higher Education and Training, 2013, The organising framework for occupations 2013, Department of Higher Education and Training, Pretoria.

South African Qualifications Authority (SAQA), 2015, National qualifications framework Sub-frameworks and qualification type, viewed 13 November 2015, from http:// www.saqa.org.za/docs/brochures/2015/updated $\% 20$ nqf $\% 20$ levevl $\% 20$ descriptors.pdf

South African Reserve Bank (SARB), 2014, Full quarterly bulletin, no. 272, SARB Pretoria, viewed 10 June 2014, from https://www.resbank.co.za/Lists/News $\% 20$ and $\% 20$ Publications/Attachments/6273/01Full\%20Quarterly\%20Bulletin $\% 20$ $\%$ E2\%80\%93\%20June $\% 202014$.pdf
Thomas, J., 2015, Review of best practices in labour market forecasting with an application to the Canadian aboriginal population, viewed 28 October 2015, from http://www.csls.ca/reports/csls2015-16.pdf

Whiteford, A., van Zyl, E., Simkins, C. \& Hall, E., 1999, SA Labour market trends and future workforce needs 1998-2003, HSRC, Pretoria.

Wong, J.M.W., Chan, A.P.C. \& Chiang, Y.H., 2004, 'A critical review of forecasting models to predict manpower demand', The Australian Journal of Construction Economics and Building 4(2), 43-56. https://doi.org/10.5130/ajceb.v4i2.2930

World Tourism Organization (UNWTO) \& International Labour Organization (ILO) 2014, Measuring employment in the tourism industries: Guide with best practices, UNWTO, Madrid, viewed 10 May 2015, from http://www.e-unwto.org/doi/ pdf/10.18111/9789284416158

World Travel \& Tourism Council (WTTC), 2015a, Travel \& tourism economic impact 2015: World, WTTC, London.

World Travel \& Tourism Council (WTTC), 2015b, Travel \& tourism economic impact 2015: South Africa, WTTC, London.

Zhou-Grundy, Y. \& Tuner, L.W., 2014, 'The challenge of regional tourism demand forecasting: The case of China', Journal of Travel Research 53(6), 747-759. https:// doi.org/10.1177/0047287513516197 